\title{
Umbria-Marche Basin, Central Italy: A Reference Section for the Aptian-Albian Interval at Low Latitudes
}

\author{
by Rodolfo Coccioni, Luigi Jovane, Giuseppe Bancalà, Carla Bucci, Gerson Fauth, \\ Fabrizio Frontalini, Liliane Janikian, Jairo Savian, Renato Paes de Almeida,

\section{Introduction}

Within the Cretaceous Period, the Aptian-Albian interval (125-99.6 Ma, Ogg et al., 2008) was a critical time on a global scale. This is evident from 1) changes in the nature of the ocean-climate system brought about by increased ocean crust production coupled with active midplate and plate margin volcanism in a shifting paleogeography (Skelton et al., 2003); 2) cyclic deposition and preservation of common "black shales", some of them termed Oceanic Anoxic Events (OAE1a to OAE1d) (Schlanger and Jenkyns, 1976; Arthur et al., 1990); 3) periodic changes in redox conditions at the ocean bottom (Oceanic Red Beds, ORBs) (Wang et al., 2009); and 4) rapid biotic radiations and turnovers (Leckie et al., 2002). The Aptian-Albian time is also of interest for one of the most noteworthy geomagnetic events, namely the post-M0r "Cretaceous Quiet Zone". This long and constant normal polarity superchron without any convincing true reversal to date (Satolli et al., 2008) precludes usage of reversals magnetostratigraphy from the Aptian through the Santonian.

The Poggio le Guaine core was designed to provide a high-resolution age model and a high-resolution relative magnetic paleointensity reference curve for the Aptian-Albian interval of the long normal Cretaceous superchron; it was also designed to understand the causal linkages among geo- logical, biogeochemical, oceanographic and climatic events as well as their consequences. The core was drilled at Poggio le Guaine, where the most continuous, complete, and best preserved Aptian-Albian succession is exposed throughout the Umbria-Marche Basin (UMB) of the northern Apennines of central Italy (Fig. 1). It represents a continuous record of fossiliferous pelagic rocks extending from the Albian-Cenomanian boundary down to the uppermost Barremian (99.6-126 Ma). In this progress report we present the first preliminary findings of this ongoing project.

\section{Geological and Stratigraphic Setting}

After three decades of dedicated research, the AptianAlbian pelagic succession of the UMB has become a classical reference section for studies at a regional to global scale. It deposited well above the calcite compensation depth at middle to lower bathyal depths (1000-1500 m) and at $\sim 20^{\circ} \mathrm{N}$ paleolatitude over the southern margin of the western Tethys Ocean (Arthur and Premoli Silva, 1982; Coccioni et al., 1987, 1989, 1990, 1992; Erba, 1988, 1992; Cresta et al., 1989; Tornaghi et al., 1989; Coccioni, 1996; Coccioni and Galeotti, 1993; Satolli et al., 2008; Tiraboschi et al., 2009; Turchyn et al., 2009).

This succession extends from the uppermost part of the Maiolica Formation (Tithonian to lower Aptian) to the lower part of the Scaglia Bianca Formation (uppermost Albian to lowermost Turonian) and includes the entire Marne a Fucoidi Formation (Fig. 2). The uppermost part of the Maiolica Formation is represented by thin-bedded white to gray limestones interbedded with black shales. The lower part of the Scaglia Bianca Formation is characterized by thin-bedded yellowish-gray lime-stones with subordinate reddish limestones and some discrete thin black shales, which are the regional sedimentary expression of the latest Albian OAE1d (Fig. 2). Within the Cretaceous succession of the UMB, the Aptian-Albian Marne a Fucoidi Formation represents a distinctive varicolored interlude with more shale. This formation consists of thinly interbedded pale reddish to dark reddish, pale olive to dark reddish brown and pale olive to grayish olive marl- 
stones and calcareous marlstones together with dark gray to black organic carbon-rich shales, usually with a low carbonate content, and yellowish-gray to light gray marly limestones and lime-stones (Fig. 2). Several distinctive organic-rich black shale and marl marker beds occur within the Aptian-Albian interval, some of which have been identified as the regional sedimentary expression of OAE1a to OAE1d (Coccioni et al., 1987, 1989, 1990; Coccioni, 1996, 2001).

Following the timescale of Ogg et al. (2008), the sediment accumulation rate is estimated to be $\sim 0.24 \mathrm{~cm} \mathrm{kyr}^{-1}$ and $\sim 0.5 \mathrm{~cm} \mathrm{kyr}^{-1}$ in the Aptian and Albian, respectively.

\section{Drilling Site Location and Drilling Operations}

The Poggio le Guaine succession was selected as the reference section for the Aptian-Albian interval following previous detailed stratigraphic investigations (Coccioni et al., 1987, 1989, 1990; Coccioni, 1996).

The Poggio le Guaine drill site (lat. $43^{\circ} 32^{\prime} 42.72^{\prime \prime} \mathrm{N}$; long. $12^{\circ} 32^{\prime} 40.92^{\prime \prime} \mathrm{E}$ ) is located on the Monte Nerone ridge at $888 \mathrm{~m}$ above sea level, $6 \mathrm{~km}$ west of the town of Cagli (Regione Marche, Italy) (Fig. 1). The outcropping beds show a strike of $310^{\circ}$ and a dip of $30^{\circ}$ to the northeast.

The drilling campaign took place on 1-14 September 2010. Drilling operations were performed with the Atlas Copco Mustang 5-F4 surface core drilling rig (Fig. 3). Coring was accomplished with a T2 double corer, using narrow-kerf, sawtoothed drill bits that cut a $10.1-\mathrm{cm}$-diameter hole and approximately 8 -cm-diameter cores. The target interval was successfully encountered below the weathering zone, which is only a couple of decimeters thick. Lithologies were logged and digital color photographs taken, as each core section was recovered (Fig. 4). Later, the seventy-one cores drilled were packed, labeled, and put in PVC plastic boxes to prevent contamination and loss of moisture. During core packing, care was taken in collecting the fragments from the few fractured portions in plastic bags. The entire core is stored at the

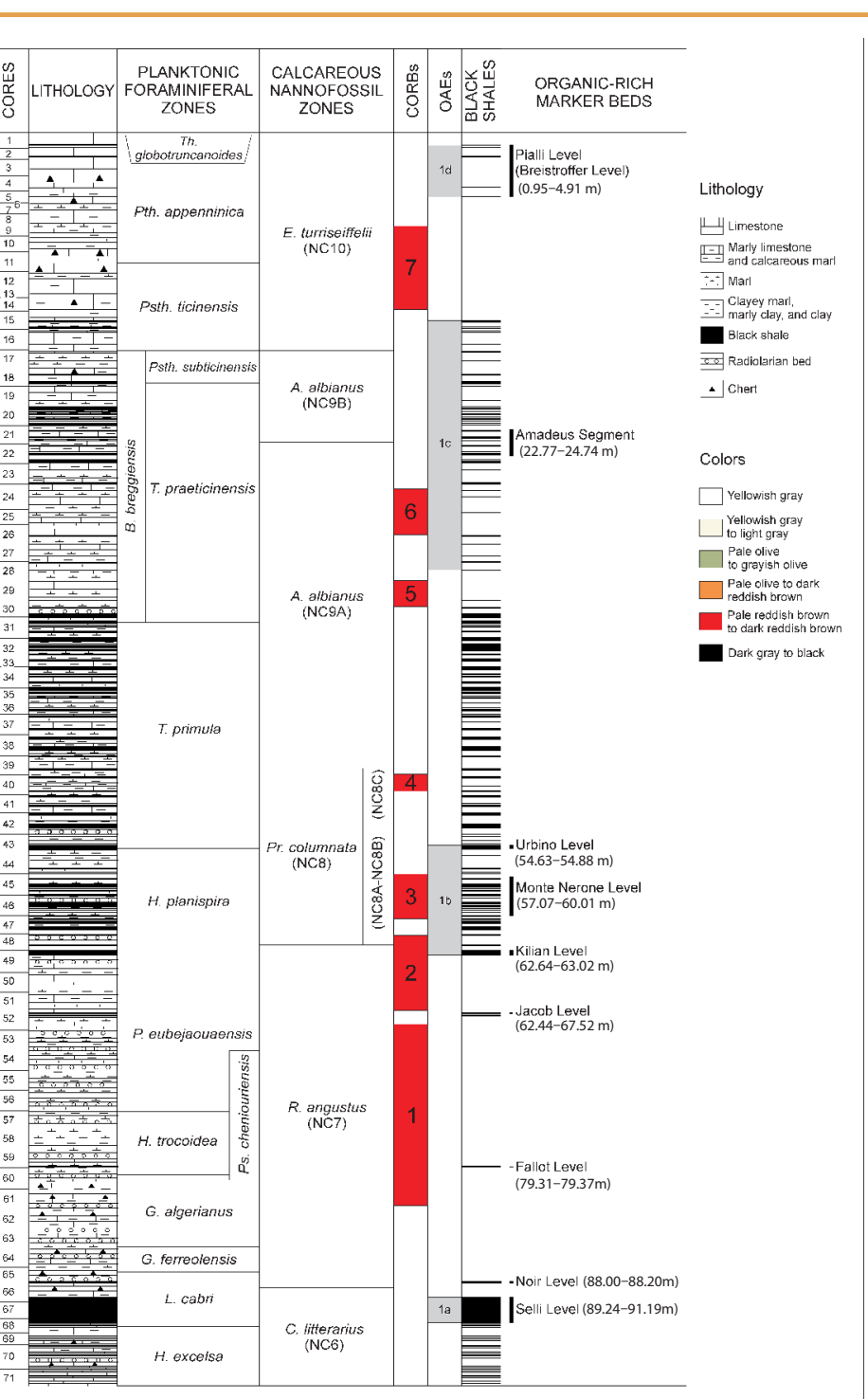

Stratigraphic framework of the Poggio le Guaine core with real stratigraphic depths according to bed dip measurements. Also shown are the occurrence and distribution of the and the discrete intervals where reddish colored beds become dominant (Cretaceous Oceanic 1989, 1990, 1992, 2007), Erba (1988, 1992), Tornaghi et al. (1989), Tiraboschi et al. (2009) and $\mathrm{H} .=$ Hedbergella, L.=Leupoldina, G.=Globigerinelloides, P.=Paraticinella, Ps.=Pseudoplanomalina, $\mathrm{T} .=$ Ticinella, B.=Biticinel/a, Psth.=Pseudothalmannine/la, Pth.=Parathalmanninel/a, Th.=Thalmanninella, C.=Chiastozygus, $\mathrm{Pa} .=$ Parhabdolithus, N.=Nannoconus, Pr.=Predicosphaera, A.=Axopodorhabdus, R.=Rhagodiscus, E.=Eiffellithus. Timescale is after Ogg et al. (2008). Following Huber and Leckie (2011), the Aptian-Albian boundary is placed at the highest occurrence of Paraticinella eubejaouaensis. 
the core, the latter particularly affected by folding and minor faulting. Taking into account the dip measurements, the corrected thickness of the drilled section is $96.02 \mathrm{~m}$, with $82.53 \mathrm{~m}$ corresponding to the Marne a Fucoidi Formation, $3.51 \mathrm{~m}$ corresponding to the underlying Maiolica Formation, and $9.98 \mathrm{~m}$ corresponding to the overlying Scaglia Bianca Formation (Fig. 2).

\section{Litho-, Bio-, and Chronostratigraphy of the Poggio le Guaine Core}

On the basis of dominant colors determined with the Munsell Rock Color Chart, the pattern of alternating colors, the calcium carbonate content, the occurrence of black shales, chert and radiolarian-rich beds, and by direct comparison with previous results from an adjacent outcrop (Coccioni et al., 1987, 1989, 1990), the Poggio le Guaine core was subdivided into twenty-three lithological units, which are recognizable on a regional scale (Coccioni, 1996; Fig. 2). Unit 1 to part of Unit 4 corresponds to the Scaglia Bianca Formation, and part of Unit 4 to the upper part of Unit 23 corresponds to the Marne a Fucoidi Formation. The Maiolica Formation is equated with most of Unit 23.

A total of two hundred forty organic-rich black shales and marls, millimeters to decimeters thick, is recorded in the cored sequence. These layers are not evenly distributed throughout the core. They are frequent to common in Units 2, 5 to 7, 9 to 15,22 and 23 that are dominated by lithotypes that are pale olive to grayish olive and yellowish gray to light gray, and occasionally by pale olive and pale reddish brown to dark reddish brown (Fig. 2). Some of these organic-rich beds record OAE1a to OAE1d, namely the lower Aptian Selli Level (OAE1a, 124 Ma), the uppermost Aptian Jacob Level, the lowermost Albian Kilian Level, the lower Albian Monte Nerone Level and the Urbino Level (all added to OAE1b, 110-113 Ma), the upper Albian Amadeus Segment (equivalent to part of OAE1c, $105 \mathrm{Ma}$ ) and the uppermost Albian Pialli Level (OAE1d, 100.5 Ma). Some others are interpre-

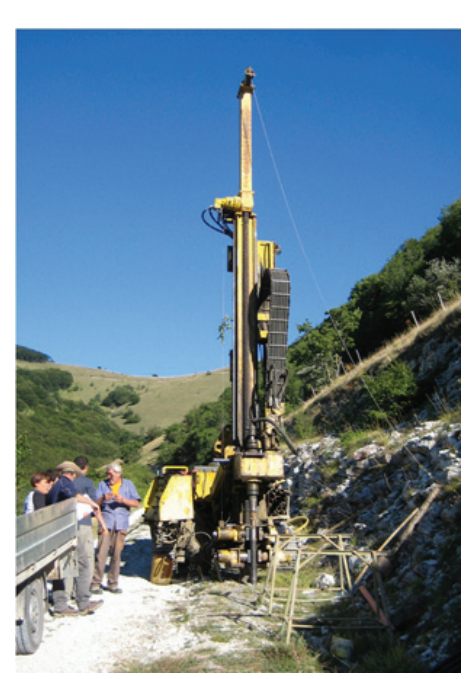

Figure 3. Drilling operations at Poggio le Guaine. ted as regional equivalents of widely distributed OAEs, namely the lower Aptian Noir Level and the middle to upper Aptian Fallot Level (Herrle al., 2004; Figs. 2, 4).

Seven discrete intervals dominantly reddish are also recognized in the cored sequence, which correlate well with those identified as ORBs in the Aptian-Albian succession of the UMB (Hu et al., 2005; Fig. 2).
In agreement with previous detailed stratigraphic investigations from Aptian-Albian land-based sections throughout the UMB (Coccioni et al., 1987, 1989, 1990, 1992; Cresta et al., 1989; Coccioni and Galeotti, 1993; Coccioni 1996, 2001, 2002) and from an 84-m-thick core drilled at Piobbico (Fig. 1) in 1982 and extending from the upper Albian down to the uppermost Barremian (Erba, 1988, 1992; Tornaghi et al., 1989), the cored succession biostratigraphically represents the interval from the Hedbergella excelsa to the base of the Thalmanninella globotruncanoides planktonic foraminiferal zones and from the Chiastozygus litterarius (NC6) to the Eiffellithus turriseiffelii (NC10) calcareous nannofossil zones. Accordingly, from a chronostratigraphic point of view the Poggio le Guaine core encompasses the latest Barremian to earliest Cenomanian interval (Fig. 2).

\section{Objectives}

The Poggio le Guaine core, which can be considered as a reference section for the Aptian-Albian interval at low latitudes, is designated by a consortium of Italian and Brazilian researchers to provide high-ranking informative records for that critical time interval through high-resolution multiproxy studies. The studies already in progress include integrated stratigraphic and sedimentological analyses, multidisciplinary magneto-, bio-, and chemostratigraphy, as well as clay and organic geochemistry investigations.

The data set collected will supply the framework for the following three activities. 1) Computing a high-resolution magnetostratigraphy, in particular a relative paleointensity reference curve for the Aptian-Albian interval of the long normal Cretaceous superchron, will allow correlation of relative paleointensity curves from other places in the world. 2) A unique and original age model can be built up, at high-resolution and using absolute dating and astronomical tuning. Into this the sequence of the geological, biogeochemical, oceanographic and climatic events that are recorded throughout the Aptian-Albian critical time can be placed. 3) The causal linkages, as well as their consequences, among these events can be defined.

\section{Acknowledgments}

The Poggio le Guaine core is an integral part of the Magnetic Anomaly of Relative Intensity for the Aptian (MARIA) project. Coring was funded by Petróleo Brasileiro S.A. - Petrobras. The Università Agraria di Secchiano (Cagli, Regione Marche, Italy) generously granted access and facilitated drilling. We warmly thank Glen Hill, Thomas Wiersberg, Mika Saido and the Editor Kevin Johnson for their helpful comments. 

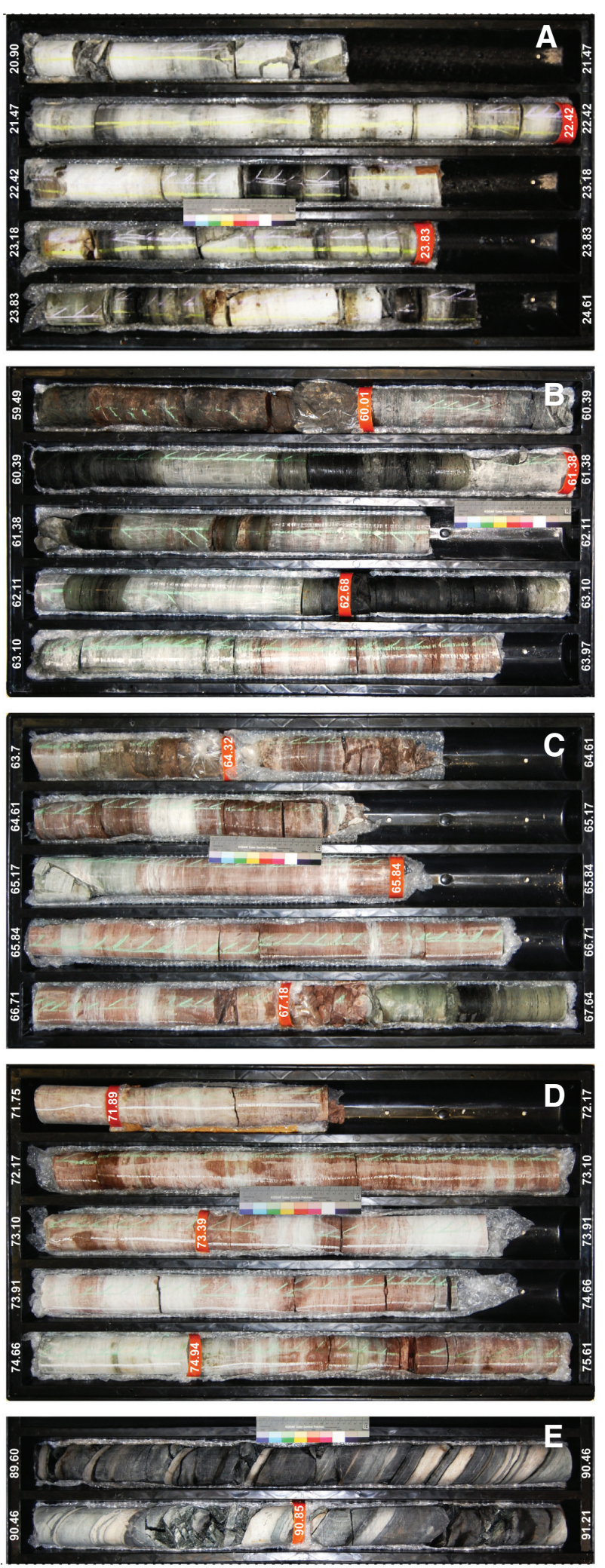

Photographs of selected cores recovered at Poggio le Guaine. [A] Cores 20 (20.90-22.45 m) to $22(23.83-25.39 \mathrm{~m})$ penetrated the marly limestones, marls, and black shales of the upper Albian Amadeus Segment (OAE1c); [B] Cores 46 $(58.42-60.01 \mathrm{~m})$ to $49(62.68-64.33 \mathrm{~m})$ recovered the marly clays, clays, marls, and black shales of the lower Albian Monte Nerone and Kilian Levels (OAE1b); [C] Cores 49 (62.68-64.33 m) to 52 (67.18-68.77 m) penetrated latest Aptian marls and calcareous marls together with the black shales of the uppermost Aptian Jacob Level (OAE1b); [D] Cores 54 (70.32-71.89 m) to 57 (74.94-76.45 m) recovered late Aptian marls, marly clays, and calcareous marls; [E] Cores $66(88.00-89.60 \mathrm{~m})$ to $68(90.85-91.99 \mathrm{~m})$ penetrated the lower Aptian Selli Level (OAE1a)

\section{References}

Arthur, M.A., and Premoli Silva, I., 1982. Development of widespread organic carbon-rich strata in the Mediterranean Tethys. In Schlanger, S.O., and Cita, M.B. (Eds.), Nature of Cretaceous Carbon-Rich Facies: San Diego (Academic Press), 7-54.

Arthur, M.A., Jenkyns, H.C., Brumsack, H.-J., and Schlanger, S.O., 1990. Stratigraphy, geochemistry, and paleoceanography of organic-carbon-rich Cretaceous sequences. In Ginsburg, R.N., and Beaudoin, B. (Eds.), Cretaceous Resources, Events and Rhythms. NATO ASI Ser. 304: Dordrecht, Netherlands (Kluwer Acad.), 75-119.

Coccioni, R., 2002. Stop 5 - The proposed global boundary stratotype section and point (GSSP) for the Barremian-Aptian boundary at Gorgo a Cerbara. In Santantonio, M. (Ed.), General Field Trip Guidebook. 6th International Symposium on the Jurassic System, 12-22 September 2002, Palermo, 239-241.

Coccioni, R., 1996. The Cretaceous of the Umbria-Marche Apennines (Central Italy). Jost Wiedmann Symposium on Cretaceous Stratigraphy, Paleobiology and Paleobiogeography, Tübingen, 7-10 March 1996, 129-136.

Coccioni, R., 2001. The "Pialli Level" from the latest Albian of the Umbria-Marche Apennines (Italy). Federazione Italiana di Scienze della Terra, Geoitalia 2001, 192-193.

Coccioni, R., and Galeotti, S., 1993. Orbitally induced cycles in benthonic foraminiferal morphogroups and trophic structures distribution patterns from the Late Albian "Amadeus Segment” (Central Italy). J. Micropaleontol., 12:227-239. doi:10.1144/jm.12.2.227

Coccioni, R., Erba, E., and Premoli Silva, I., 1992. Barremian-Aptian calcareous plankton biostratigraphy from the Gorgo a Cerbara section (Marche, Central Italy) and implications for plankton evolution. Cret. Res., 13:517-537. doi:10.1016/0195-6671(92)90015-I

Coccioni, R., Franchi, R., Nesci, O., Wezel, F.C., Battistini, F., and Pallecchi, P., 1989. Stratigraphy and mineralogy of the Selli Level (Early Aptian) at the base of the Marne a Fucoidi in the Umbro-Marchean Apennines, Italy. In Wiedmann, J. (Ed.), Cretaceous of the Western Tethys. Proceedings 3rd International Cretaceous Symposium, Stuttgart (E. Schweizerbart'sche Verlagsbuchhandlung), 563-584.

Coccioni, R., Franchi, R., Nesci, O., Perilli, N., Wezel, F.C., and Battistini, F., 1990. Stratigrafia, micropaleontologia e mineralogia delle Marne a Fucoidi delle sezioni di Poggio le Guaine e del Fiume Bosso (Appennino umbro-marchigiano). Atti $2^{\circ}$ Convegno Internazionale "Fossili, Evoluzione, Ambiente”, Pergola, 25-30 ottobre 1987, Tecnostampa, 163-201.

Coccioni, R., Nesci, O., Tramontana, M., Wezel, F.C., and Moretti, E., 1987. Descrizione di un livello-guida "radiolaritico-bituminoso-ittiolitico" alla base delle Marne a Fucoidi nell'Appennino umbro-marchigiano. Boll. Soc. Geol. Italiana, 106:183-192.

Coccioni, R., Premoli Silva, I., Marsili, A., and Verga, D., 2007. First radiation of Cretaceous planktonic foraminifera with radially elongate chambers at Angles (Southeastern France) and biostratigraphic implications. Rev. micropaléontologie, 50:215-224. 
Cresta, S., Monechi, S., and Parisi, G., 1989. Stratigrafia del Mesozoico al Cenozoico nell'area Umbro-Marchigiana. Mem. Descr. Carta Geol. Italia, 34:185.

Erba, E., 1988. Aptian-Albian calcareous nannofossil biostratigraphy of the Scisti a Fucoidi cored at Piobbico (central Italy). Riv. Ital. Paleont. Strat., 94:249-284.

Erba, E., 1992. Calcareous nannofossil distribution in pelagic rhythmic sediments (Aptian-Albian Piobbico core, central Italy). Riv. Ital. Paleont. Strat., 97:455-484.

Herrle, J.O., Kössler, P., Friedrich, O., Erlenkeuser, H., and Hemleben, C., 2004. High-resolution carbon isotope records of the Aptian to Lower Albian from SE France and the Mazagan Plateau (DSDP Site 545): A stratigraphic tool for paleoceanographic and paleobiologic reconstruction. Earth Planet. Sci. Lett., 218:149-161. doi:10.1016/S0012821X(03)00646-0

Hu, X., Jansa, L., and Sarti, M., 2005. Mid-Cretaceous oceanic red beds in the Umbria-Marche Basin, central Italy: Constraints on paleoceanography and paleoclimate. Palaeogeogr. Palaeoclimatol. Palaeoecol., 233:163-186. doi:10.1016/j. palaeo.2005.10.003

Huber, B.T., and Leckie, R.M., 2011. Planktic foraminiferal species turnover across deep-sea Aptian/Albian boundary sections. J. Foram. Res., 41:53-95. doi:10.2113/gsjfr.41.1.53

Leckie, R.M., Bralower, T.J., and Cashman, R., 2002. Oceanic anoxic events and plankton evolution: Biotic response to tectonic forcing during the mid-Cretaceous. Paleoceanogr., 17:13-1-13-29. doi: 10.1029/2001PA000623

Ogg, J.G., Ogg, G., and Gradstein, F.M., 2008. The Concise Geologic Time Scale: Cambridge (Cambridge University Press).

Satolli, S., Besse, J., and Calamita, F., 2008. Paleomagnetism of Aptian-Albian sections from the Northern Apennines (Italy): Implications for the 150-100 Ma apparent polar wander of Adria and Africa. Earth Planet. Sci. Lett., 276:115-128. doi:10.1016/j.eps1.2008.09.013

Schlanger, S.O., and Jenkyns, H.C., 1976. Cretaceous oceanic anoxic events: Causes and consequences. Geol. Mijnbouw, 55:179-184.

Skelton, P.W., Spicer, R.A., Kelley, S.P., and Gilmour, I., 2003. The Cretaceous World: Cambridge (Cambridge University Press).

Tiraboschi, D., Erba, E., and Jenkyns, H.C., 2009. Origin of rhythmic Albian black shales (Piobbico core, central Italy): Calcareous nannofossil quantitative and statistical analyses and paleoceanographic reconstructions. Paleoceanogr., 24:PA2222. doi:10.1029/2008PA001670

Tornaghi, M.E., Premoli Silva, I., and Ripepe, M., 1989. Lithostratigraphy and planktonic foraminiferal biostratigraphy of the Aptian-Albian "Scisti a Fucoidi" in the Piobbico core, Marche, Italy: Background for cyclostratigraphy. Riv. Ital. Paleont. Strat., 95:223-264.

Turchyn, A.V., Schrag, D.P., Coccioni, R., and Montanari, A., 2009. Stable isotope analysis of the Cretaceous sulfur cycle. Earth Planet. Sci. Lett., 285:115-123.

Wang, C., Hu, X., Huang, Y., Scott, R.W., and Wagreich, M., 2009. Overview of Cretaceous Oceanic Red Beds (CORBs): A window on global oceanic and climate change. In Hu, X., Wang, C., Scott, W., Wagreich, M., and Jansa, L. (Eds.), Oceanic
Red Beds: Stratigraphy, Composition, Origins, and Paleoceanographic and Paleoclimatic Significance. Society for Sedimentary Geology, Special Publication, 91:13-33.

\section{Authors}

Rodolfo Coccioni, Dipartimento di Scienze della Terra, della Vita e dell'Ambiente dell'Università degli Studi "Carlo Bo," Campus Scientifico "E. Mattei”, Località Crocicchia, 61029 Urbino, Italy, e-mail: rodolfo.coccioni@uniurb.it.

Luigi Jovane, Departamento de Oceanografia Física, Instituto Oceanográfico, Universidade de São Paulo, 05508900 São Paulo, Brazil.

Giuseppe Bancalà, Dipartimento di Scienze della Terra, della Vita e dell'Ambiente dell'Università degli Studi "Carlo Bo," Campus Scientifico "E. Mattei”, Località Crocicchia, 61029 Urbino, Italy.

Carla Bucci, Dipartimento di Scienze della Terra, della Vita e dell'Ambiente dell'Università degli Studi "Carlo Bo," Campus Scientifico "E. Mattei”, Località Crocicchia, 61029 Urbino, Italy.

Gerson Fauth, Centro de Ciências Exatas e Tecnológicas, Área de Conhecimento e Aplicação de Geociências, Universidade do Vale do Rio dos Sinos, São Leopoldo, Brazil. Fabrizio Frontalini, Dipartimento di Scienze della Terra, della Vita e dell'Ambiente dell'Università degli Studi "Carlo Bo," Campus Scientifico "E. Mattei”, Località Crocicchia, 61029 Urbino, Italy.

Liliane Janikian, Departamento de Geofísica, Instituto de Astronomia, Geofísica e Ciências Atmosféricas, Universidade de São Paulo, 05508-090 São Paulo, Brazil.

Jairo Savian, Departamento de Geofísica, Instituto de Astronomia, Geofísica e Ciências Atmosféricas, Universidade de São Paulo, 05508-090 São Paulo, Brazil.

Renato Paes de Almeida, Departamento de Geologia Sedimentar e Ambiental, Instituto de Geociências, Universidade de São Paulo, 05508-090 São Paulo, Brazil.

Grasiane Luz Mathias, Departamento de Geofísica, Instituto de Astronomia, Geofísica e Ciências Atmosféricas, Universidade de São Paulo, 05508-090 São Paulo, Brazil

Ricardo Ivan Ferreira da Trindade, Departamento de Geofísica, Instituto de Astronomia, Geofísica e Ciências Atmosféricas, Universidade de São Paulo, 05508-090 São Paulo, Brazil.

\section{Photo Credits}

Figs. 3 and 4: Rodolfo Coccioni, Urbino University 